Connecticut, Pennsylvania and Ohio, the seven industrial States of the Northeastern section of the country. This Committee has agreed on an unemployment reserves proposal that may be made the basis of legislative action at the next session of the legislatures of these States. This action, if taken and approved, will remove to some degree the objection that, unless any burdens on industry resulting from legislation of this character are generally applied, unjust inequalities in competition for business may result.

There is another viewpoint of considerable weight that is having its effect in molding opinion both of business and the public generally. Regardless of how soon we may emerge from the depths of the present depression, it is thought by many that we shall have unemployment persisting in more or less serious form for a long period. Consideration of the unemployment problem may, therefore, be continuous and progressive as a social and economic necessity. It seems certain that, unless preventive measures are established to reduce the severity of future unemployment, expensive palliatives through political action will result.

If this depression teaches us the necessity of developing preparedness steps to attack the problem at its source, it will not only take on a trait which will distinguish it from its predecessors, but will exert as well a marked influence on business cycles of the future.

\title{
Twenty-seven Years of Business Investment 1832-1859
}

There have come to Baker Library, from two different sources, six account books of modest proportion which have, packed within their pages, the complete record of the investments of one of Boston's outstanding citizens - outstanding both for his ability and his public spirit. His well-ordered accounts should constitute a mine of information for research students. Even the most hasty review of the records brings to light information of great interest.

In 1827 this man returned to Boston from Canton, after twentyfive years of active participation in the China Trade. He was then worth over $\$ 800,000$ - considerable wealth for that time. During the following twenty-seven years he was to increase that wealth to over $\$ 2, \infty 00,000$. His capital was distributed through eight different forms of investment. The accompanying chart shows the relative growth of these investments throughout the twenty-seven years. From the pages of the accounts might be learned the rate of return for every share of stock held. He himself summarized the informa- 
tion by tabulating his estimate of the rate of return on each type of investment for each year, along with the average for the twentyseven years.

It is interesting to note that the man was not a speculator. $\mathrm{He}$ bought stocks, but seems rarely to have sold them. Often he acquired stock as an initial investor in a firm. He held substantial blocks of stock in seventeen different manufacturing concerns and some sixteen different railroads, not to mention his holdings in rea] estate, bank stocks, insurance stocks, and large accounts of money loaned out to private individuals.

Rates of INCOME From I 833 TO 1858

Year Rents Manufactures Railroads Insurance Banks Loans

\begin{tabular}{|c|c|c|c|c|c|c|}
\hline 1833. & $7 \cdot 7$ & $34 \cdot 3$ & . & 8.2 & 4.8 & 4.4 \\
\hline $1834 \ldots \ldots$ & 6.9 & 9.9 & . & 10.6 & 7.0 & 5.1 \\
\hline $1835 \ldots \ldots$ & 5.8 & 16.4 & .. & 12.6 & 6.6 & $4 \cdot 3$ \\
\hline $1836 \ldots \ldots$ & 5.2 & 13.2 & . . & 21.0 & 8.2 & 5.0 \\
\hline $1837 \ldots \ldots$ & 5.8 & 2.7 & 4.4 & 11.0 & 6.9 & 5.8 \\
\hline $1838 \ldots \ldots$ & 7.2 & 4.8 & 5.4 & 8.0 & 3.2 & $4 \cdot 7$ \\
\hline I839. . & 6.6 & 7.2 & 12.1 & 7.1 & 6.6 & 6.7 \\
\hline $1840 \ldots \ldots$ & 8.5 & 4.7 & 6.3 & 9.2 & 4.1 & $5 \cdot 7$ \\
\hline $1841 \ldots$ & 8.3 & 9.2 & 7.0 & $13 \cdot 4$ & 6.8 & $7 \cdot 5$ \\
\hline $1842 \ldots \ldots$ & 7.1 & 4.2 & 7.1 & 14.6 & $7 \cdot 3$ & 6.2 \\
\hline $1843 \ldots$ & $7 \cdot 9$ & 8.0 & $5 \cdot 9$ & I9. 7 & 6.3 & 6.6 \\
\hline I $844 \ldots$ & $7 \cdot 5$ & 15.6 & 7.0 & 15.0 & 5.8 & $4 \cdot 3$ \\
\hline $1845 \ldots \ldots$ & 7.9 & 18.3 & $7 \cdot 7$ & 16.5 & 6.2 & $4 \cdot 7$ \\
\hline 1846. & 6.7 & 14.0 & 7.2 & 7.6 & 6.7 & 6.0 \\
\hline 1847. & 7.2 & 8.6 & 8.0 & 9.8 & 7.2 & 6.1 \\
\hline 1848. & 6.4 & 5.0 & 10.1 & 9.2 & 7.6 & 7.2 \\
\hline $1849 \ldots$ & 6.6 & 6.7 & 8.4 & 8.9 & 8.2 & 6.2 \\
\hline 1850. & 6.3 & 6.5 & 12.9 & 15.9 & 7.8 & 5.9 \\
\hline $1851 \ldots$ & 8.3 & 3.8 & 8.I & 13.4 & 8.0 & 6.1 \\
\hline $1852 \ldots \ldots$ & $7 \cdot 5$ & 5.2 & 8.8 & II 1.7 & $7 \cdot 3$ & 6.9 \\
\hline $1853 \ldots \ldots$ & 7.6 & $7 \cdot 5$ & 10.3 & 8.2 & 7.8 & 7.2 \\
\hline $1854, \ldots \ldots$ & $7 \cdot 5$ & 6.8 & 8.2 & 4.9 & $7 \cdot 4$ & 6.2 \\
\hline $1855 \ldots \ldots$ & 5.9 & 4.2 & 10.2 & 7.6 & $7 \cdot 5$ & $7 \cdot 4$ \\
\hline $1856 \ldots \ldots$ & 6.2 & 6.4 & 6.8 & II.7 & 8.0 & 6.4 \\
\hline $1857 \ldots$ & 6.3 & 4.6 & $7 \cdot 4$ & 10.5 & 7.8 & $7 \cdot 4$ \\
\hline $105^{\circ}$ & 6.2 & 4.6 & I 6.4 & 17.0 & 7.8 & 6.0 \\
\hline Average ... & 7.0 & 8.9 & 8.4 & I 1.6 & 7.0 & 6.1 \\
\hline
\end{tabular}


Investments $1832-1859$

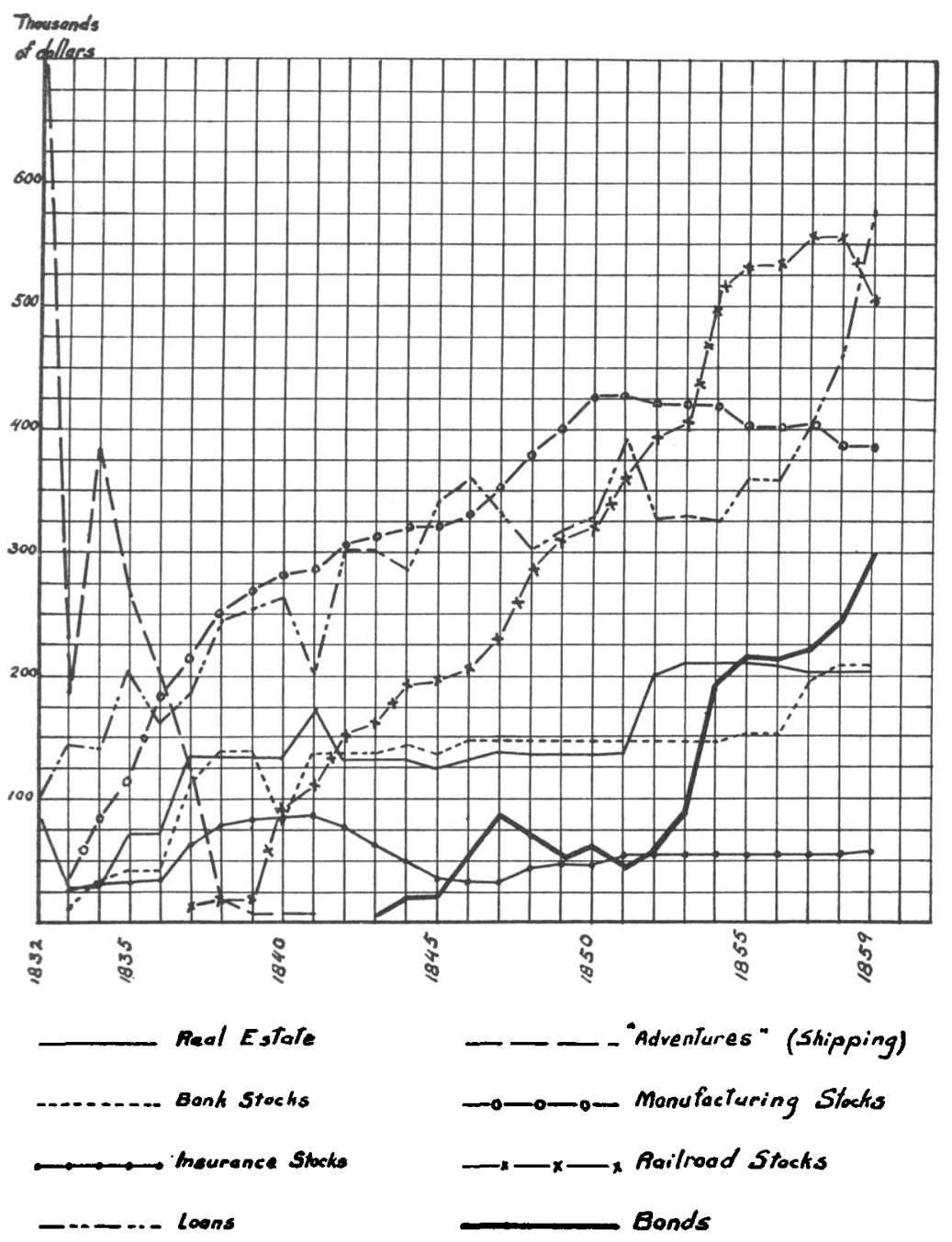

$[15]$

https://doi.org/10.1017/S0007680500019929 Published online by Cambridge University Press 